\title{
Subtropical Shelf Front off eastern South America
}

\author{
Alberto R. Piola, ${ }^{1,2}$ Edmo J.D. Campos, ${ }^{3}$ Osmar O. Möller Jr, ${ }^{4}$ \\ Marcela Charo, ${ }^{\prime}$ and Carlos Martinez ${ }^{5}$
}

\begin{abstract}
Historical hydrographic data from the continental shelf off eastern South America are used to examine the thermohaline properties of the water masses in the region between $20^{\circ} \mathrm{S}$ and $40^{\circ} \mathrm{S}$. The continental shelf water masses are originated by dilution of open ocean waters of the western boundary currents of the South Atlantic Ocean. On the basis of temperature-salinity relation, two distinct water masses are identified, namely, the Subantarctic Shelf Water and the Subtropical Shelf Water. Subantarctic Shelf Water originates by dilution of Subantarctic Water, primarily in the southeast Pacific, due to excess precipitation and continental runoff and enters the continental shelf near $55^{\circ} \mathrm{S}$. The Subtropical Shelf Water is modified South Atlantic Central Water diluted by continental runoff from the coast of Brazil. In addition, substantial dilution of the upper shelf waters takes place at the mouth of Río de la Plata (approximately located at $36^{\circ} \mathrm{S}$ ) and, in a lesser extent, at the Patos-Mirim Lagoon (at $32^{\circ} \mathrm{S}$ ). The Río de la Plata and the Patos outflows form a low-salinity tongue that caps the shelf water leading to a salinity decrease to values $<30$. The low-salinity tongue extends northward over the shelf penetrating farther north in winter than in summer. The extent of the low-salinity water has a strong impact on the vertical stratification and acts to limit winter convection to the layer above the halocline. There is little or no indication of mixing between Subantarctic Shelf Water and Subtropical Shelf Water. An intense temperature, salinity, and nutrient front separates these water masses. The front is oriented along the north-south direction, located on average near the $50 \mathrm{~m}$ isobath at $32^{\circ} \mathrm{S}$ and extends southward toward the shelf break near $36^{\circ} \mathrm{S}$. Between $32^{\circ}$ and $34^{\circ} \mathrm{S}$ the Subtropical Shelf Front follows the 100 to $200 \mathrm{~m}$ isobaths and separates Subantarctic Shelf Water from the oceanic South Atlantic Central

Water. On the basis of the temperature and salinity distributions, beneath the low-salinity surface layer, the Subtropical Shelf Front appears as an extension of the Brazil-Malvinas Confluence over the continental shelf of South America. Thus the location of the Subtropical Shelf Front may be linked to the migrations of the separation point of the Brazil-Malvinas Confluence from the continental slope.
\end{abstract}

\section{Introduction}

On the basis of the temperature and salinity characteristics, waters entering the continental shelf of eastern South America northeast of Cape Horn are moderately diluted subantarctic waters. Excess precipitation in the southeast Pacific and continental runoff from southern Chile reduce the salinity over the shelf to values <33.9 [Deacon, 1933; Lusquiños and Valdéz, 1971]. Further dilution takes place by way of mixing with waters entering the shelf at the Straits of Magellan near $55^{\circ} \mathrm{S}$ with salinity as low as 32.3 [Lusquiños and Valdéz,

\footnotetext{
'Departamento Oceanografia, Servicio de Hidrografia Naval, Buenos Aires, Argentina.

${ }^{2}$ Also at Departamento de Ciencias de la Atmósfera y los Océanos, Facultad de Ciencias Exactas y Naturales, Universidad de Buenos Aires, Buenos Aires, Argentina.

${ }^{3}$ Instituto Oceanográfico, Universidade de São Paulo, São Paulo, Brazil.

${ }^{4}$ Fundação Universidade do Rio Grande, Rio Grande, Brazil.

${ }^{5}$ Facultad de Ciencias, Universidad de la República, Montevideo, Uruguay.
}

Copyright 2000 by the American Geophysical Union

Paper number $1999 \mathrm{JC} 000300$.

0148-0227/00/1999JC000300\$9.00
1971; Krepper, 1977; Piola and Rivas, 1997]. In response to this inflow the salinity over the shelf increases from the coast to the shelf break where it reaches values higher than 33.8.

On the basis of property distributions [Brandhorst and Castello, 1971; Lusquiños, 1971; Lusquiños and Valdéz, 1971; Guerrero and Piola, 1997], current observations [Piola and Rivas, 1997; Rivas, 1997], and models [Lusquiños and Shrott, 1983; Forbes and Garraffo, 1988; Glorioso and Flather, 1995; Rivas and Frank Langer, 1996] at latitudes higher than $\sim 40^{\circ} \mathrm{S}$, a mean flow over the shelf toward the NNE is inferred. The intense westerlies stress over the surface appears to be the main forcing for the mean circulation over the shelf [Forbes and Garraffo, 1988; Bakum and Parrish, 1991].

North of $\sim 37^{\circ} \mathrm{S}$, however, the flow direction and intensity are more variable. This may be in part due to a substantial decrease in the westerlies north of $\sim 40^{\circ} \mathrm{S}$ and a relatively larger seasonal component in the wind stress variability [Hellerman and Rosenstein, 1983]. On the basis of a simple wind-driven model of the flow off southern Brazil and Uruguay it has been suggested that the mean flow reverses seasonally, being toward the SSW in summer and toward the NNE in winter [Pereira, 1989]. The current reversal in this model is associated to the southward displacement of the South Atlantic high-pressure cell during the summer, which causes a reversal in wind stress in the region from $30^{\circ}$ to $40^{\circ} \mathrm{S}$ [see Höflich, 
1984; Lima et al., 1996]. More recently, from the inversion of the heat conservation equation applied between $30^{\circ}$ and $35^{\circ} \mathrm{S}$, Zavialov et al. [1998] have calculated a near-surface flow toward the NNE throughout the year.

The entire area is characterized by a net annual heat gain from a maximum of $68 \mathrm{~W} / \mathrm{m}^{2}$ near $39^{\circ} \mathrm{S}$ decreasing northward to $38 \mathrm{~W} / \mathrm{m}^{2}$ north of $30^{\circ} \mathrm{S}$ [see Bunker and Goldsmith, 1979]. The highest heat input $\left(\sim 190 \mathrm{~W} / \mathrm{m}^{2}\right)$ occurs in November and December, while the heat loss to the atmosphere is maximum in May, varying between 60 and $80 \mathrm{~W} / \mathrm{m}^{2}$.

Over the shelf, south of $\sim 40^{\circ} \mathrm{S}$, evaporation exceeds precipitation by $50 \mathrm{~cm} / \mathrm{yr}$ [Höflich, 1984], and mean continental runoff is small $\left(<5000 \mathrm{~m}^{3} / \mathrm{s}\right.$ [United Nations Educational, Scientific and Cultural Organization (UNESCO), 1996]). The negative ocean mass balance induces a moderate northward salinity increase from $55^{\circ}$ to $38^{\circ} \mathrm{S}$. At $40^{\circ} \mathrm{S}$ the lowsalinity tongue $(S<33.6)$, whose origin can be traced southward to the Straits of Magellan, is located on the middle shelf [Brandhorst and Castello, 1971; Guerrero and Piola, 1997].

The major freshwater inflow into the area is associated with the Río de la Plata discharge, which averages $23.3 \times 10^{3} \mathrm{~m}^{3} / \mathrm{s}$. A secondary freshwater discharge is from the Patos-Mirim Lagoon system, located near $32^{\circ} \mathrm{S}$, averaging between 1500 and $2000 \mathrm{~m}^{3} / \mathrm{s}$ [Möller et al., 1991; Möller, 1996]. In response to the continental runoff, between $30^{\circ}$ and $36^{\circ} \mathrm{S}$, subantarctic water and subtropical waters are frequently capped by a low-salinity layer. North of $34^{\circ} \mathrm{S}$, the influence of the river discharge is stronger in winter and spring and weak in summer [Castello and Möller, 1977]. Farther north, in the Southeast Brazil Bight (SBB), between $22^{\circ}$ and $28^{\circ} \mathrm{S}$, both the dynamics and the water mass structure are influenced by open ocean intrusions caused by the frequent meandering of the Brazil Current (BC) [Miranda and Castro, 1981; Campos et al., 1995; Castro and Miranda, 1998]. Intense coastal upwelling is frequently observed in the region around Cabo Frio $\left(22^{\circ} \mathrm{S}\right)$, and Ilha de São Sebastião $\left(24^{\circ} \mathrm{S}\right)$. Wind-driven and shelf break upwelling induced by BC cyclonic meanders are believed to be responsible for pumping up nutrient-rich South Atlantic Central Water to the euphotic zone in the inner shelf [Campos et al , 1995, Matsuura, 1996].

In this paper we use historical hydrographic data collected over a period of several decades to describe the water mass characteristics and their distribution. The data handling and quality control procedures are described in section 2 . The surface water characteristics and the role and extent of continental runoff on the shelf water masses are discussed in section 3. On the basis of temperature-salinity and dissolved silicate distributions the water mass characteristics, their distribution, and seasonal variability are presented in sections 4 and 5 , and in section 6 the results are discussed.

\section{Data and Methods}

The historical hydrographic data used in this paper were obtained from the Argentine Oceanographic Data Center (CEADO). CEADO also archives data received from the $\mathrm{Na}-$ tional Data Centers in Brazil and Uruguay. Data originated by research institutions in other countries are obtained by CEADO through World Data Center-A in Washington, D.C. The station locations over the continental shelf are shown in Figure 1a. In Table 1 the stations are sorted by ship name and country. The number of stations occupied each year after
1950 is shown in Figure 1b. Prior to 1950, only five hydrographic stations, occupied in the region by $R / V$ Meteor in December 1924 and January and July 1925, are archived by CEADO. The rather long time lapse between data collection and its public availability leads to the substantial reduction in the number of stations archived in the 1990s.

Owing to the changes in methods and instrumentation during the time spanned, the data quality is heterogeneous. All stations were checked for vertical stability and temperature and salinity data leading to $\sigma_{T}$ inversions $>0.02$ were flagged as doubtful and excluded from the analysis. Quality control of silicate data was based on potential temperature-silicate scatterplots. Within $1^{\circ} \times 1^{\circ}$ areas and for each season, silicate data within $1{ }^{\circ} \mathrm{C}$ bins falling beyond two standard deviations were flagged as doubtful and excluded from the analysis.

\section{Surface Characteristics}

The distribution and seasonal variability of the surface temperature and salinity play a key role on the stratification over the shelf. Summer (January, February, and March) and winter (July, August, and September) distributions will be discussed. The surface temperature, salinity, and silicate averaged over $1^{\circ}$ latitude bands are shown in Figure 2 and in Table 2. To reflect the continental shelf characteristics, the data collected in the Patos Lagoon have been excluded from the analysis. The shelf surface layer undergoes large seasonal temperature changes (Figure 2). South of $33^{\circ} \mathrm{S}$, the amplitude of the sea surface temperature cycle exceeds $9^{\circ} \mathrm{C}$ [see Podestá et al., 1991] and reduces to $<3^{\circ} \mathrm{C}$ north of $23^{\circ} \mathrm{S}$. The decrease is gradual $\left(\sim 0.25^{\circ} \mathrm{C} /\right.$ degree latitude) south of $24^{\circ} \mathrm{S}$, but a sharp reduction in summer sea surface temperature occurs north of $24^{\circ} \mathrm{S}$. In this region the summer surface temperature variability is largest $\left(3.73^{\circ} \mathrm{C}\right.$; see Table 2$)$. Several repeat stations occupied in the area (not shown here) show large in phase temperature and salinity fluctuations. The surface $T-S$ characteristics reveal that the cold anomalies match the South Atlantic Central Water (SACW) characteristics. SACW frequently occupies the near-bottom region of the outer continental shelf [Castro et al., 1987; Campos et al., 1995; Castro and Miranda, 1998] and is upwelled to the near surface in summer in the region off Cabo Frio [Bakum and Parrish, 1990; Matsuura, 1996].

South of $37^{\circ} \mathrm{S}$, the surface salinity shows only small variations between 33.63 and 33.7 . Near $37^{\circ} \mathrm{S}$ the influence of the Río de la Plata discharge is apparent, producing a sharp freshening of the surface waters to $<25$ (Table 2) [see also Guerrero et al., 1997a, b; Framiñan et al., 1999]. A secondary source of low-salinity water is located at the mouth of Patos Lagoon, near $32^{\circ} \mathrm{S}$ [Ciotti et al, 1995; Möller, 1996]. The northward penetration of a quasi-continuous surface salinity minimum extending from Río de la Plata is apparent throughout the year (Figure 3). In summer the 33 isohaline, which indicates dilution of shelf waters, reaches $32^{\circ} \mathrm{S}$ (Figure $3 a)$, whereas in winter the isohaline extends well north of $28^{\circ} \mathrm{S}$ (Figure 3b). Thus the surface salinity distribution suggests some degree of seasonal variability in the surface circulation, in agreement with the results of Pereira [1989]. Similarly, northward penetration of low surface salinity water $(S<32)$ beyond $32^{\circ} \mathrm{S}$ over the southern Brazilian shelf is apparent in synoptic data collected in spring 1987 and winter 1988 [Lima et al., 1996, Figures 4d and 4f]. In contrast, a 

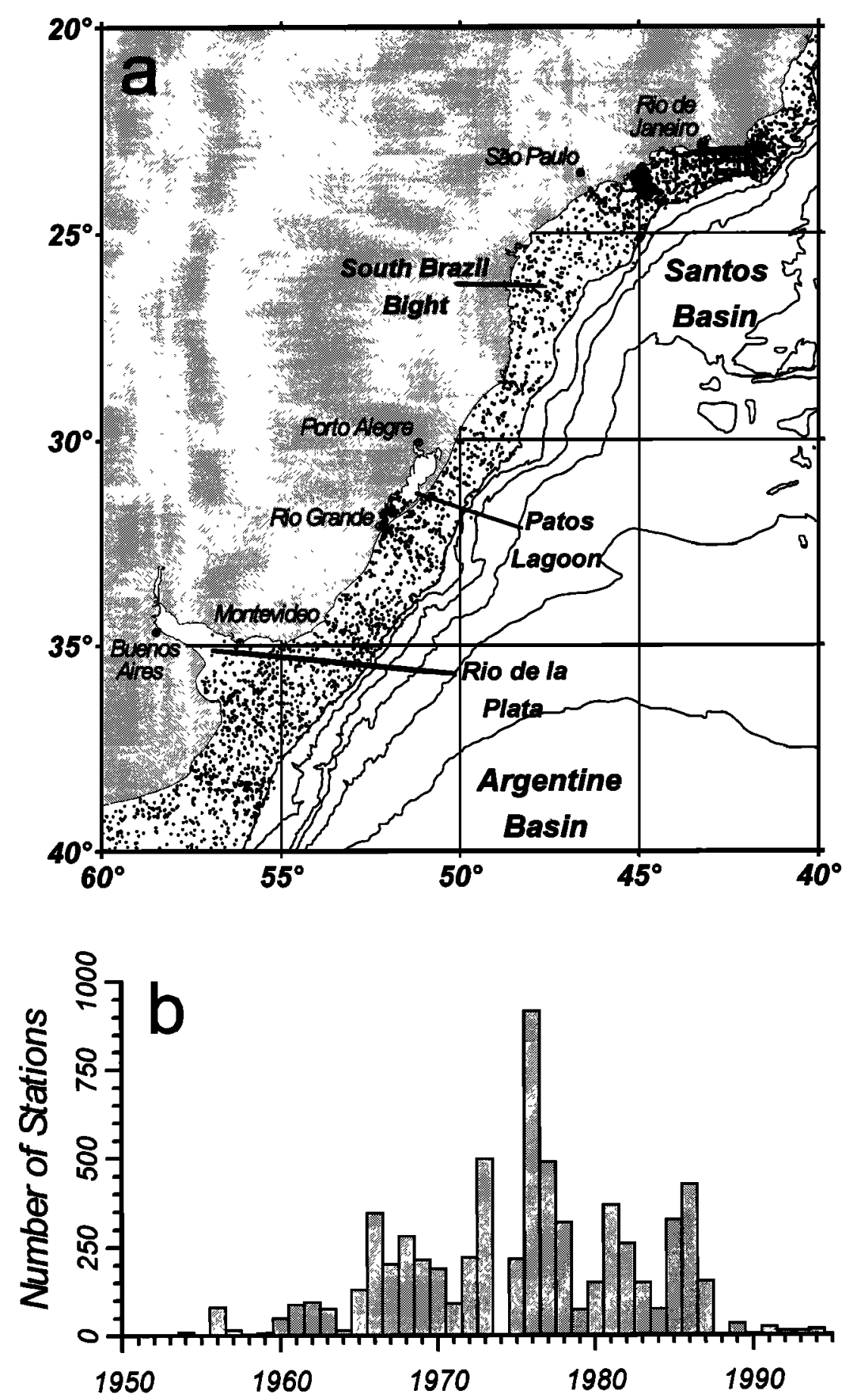

Figure 1. (a) Hydrographic stations taken over the continental shelf (bottom depth $<200 \mathrm{~m}$ ) off eastern South America. Also shown are the 200,1000,2000,3000, 4000, and $5000 \mathrm{~m}$ isobaths. (b) Yearly occupation of hydrographic stations after 1950 (only five stations were taken before 1950; see text).

limited northward extent of surface waters fresher than 34 is found in the summer of 1990. As a result of the seasonal variability, north of $30^{\circ} \mathrm{S}$, the summer surface salinity exceeds 35 , while in winter, similar values are only observed north of $25^{\circ} \mathrm{S}$ (Figure 2 and Table 2 ).

In summer, high mean surface silicate concentration $(>10$ $\mu \mathrm{mol} / \mathrm{kg}$ ) are observed between $38^{\circ}$ and $36^{\circ} \mathrm{S}$. The high values in winter extend northward up to $30^{\circ} \mathrm{S}$. The highest silicate concentrations appear to be associated with the freshwater discharge of Río de la Plata and Patos Lagoon [see Castello and Moller, 1977]. South of this region, the surface silicate is, on average, $<10 \mu \mathrm{mol} / \mathrm{kg}$, but large variations are observed. North of $30^{\circ} \mathrm{S}$, the concentration decreases to values ranging between 2 and $10 \mu \mathrm{mol} / \mathrm{kg}$ (Figure 2 and Table 2), while the higher surface silicate in the south is indicative of subantarctic influence. Thus the seasonal silicate 
Table 1. Hydrographic Data Collected on the Continental Shelf Used in This Study

\begin{tabular}{|c|c|c|c|}
\hline Ship Name & Country & Cruises & Stations \\
\hline Almirante Saldanha & Brazil & 51 & 2610 \\
\hline Capitan Canepa & Argentina & 35 & 624 \\
\hline Squalus & Brazil & 17 & 617 \\
\hline Professor $W$. Besnard & Brazil & 14 & 505 \\
\hline Miguel dos Santos & Brazil & 5 & 304 \\
\hline Almirante Camara & Brazil & 6 & 278 \\
\hline Dr. E. Holmberg & Argentina & 8 & 187 \\
\hline Orion & Brazil & 5 & 118 \\
\hline Velliger & Brazil & 2 & 109 \\
\hline Baependi & Brazil & 3 & 83 \\
\hline Shinkai Maru & Japan & 7 & 81 \\
\hline Solimoes & Brazil & 1 & 67 \\
\hline Bertioga & Brazil & 3 & 45 \\
\hline Larus & Brazil & 1 & 42 \\
\hline Capitan Oca Balda & Argentina & 3 & 33 \\
\hline Walther Herwig & Germany & 1 & 31 \\
\hline Camocim & Brazil & 1 & 28 \\
\hline El Austral & Argentina & 7 & 27 \\
\hline Ernst Haeckel & Germany & 1 & 26 \\
\hline Bracui & Brazil & 2 & 22 \\
\hline Akademik Knipovich & Russia & 1 & 19 \\
\hline Goyena & Argentina & 2 & 17 \\
\hline General San Martin & Argentina & 1 & 15 \\
\hline Coates & United States & 1 & 13 \\
\hline Kaiyo Maru & Japan & 1 & 12 \\
\hline Nasa & Brazil & 1 & 12 \\
\hline Igaraty & Brazil & 1 & 9 \\
\hline Atlantis & United States & 2 & 7 \\
\hline Iguatemi & Brazil & 1 & 7 \\
\hline Comodoro Laserre & Argentina & 1 & 6 \\
\hline Guanabara & Brazil & 1 & 6 \\
\hline General Zapiola & Argentina & 2 & 6 \\
\hline Meteor & Germany & 1 & 4 \\
\hline Mikhail Lomonosov & Russia & 1 & 2 \\
\hline$O b$ & Russia & 1 & 2 \\
\hline Thomas Washington & United States & 1 & 2 \\
\hline Edisto & United States & 1 & 1 \\
\hline Glennon & United States & 1 & 1 \\
\hline Islas Orcadas & Argentina & 1 & 1 \\
\hline Undaunted & United States & 1 & 1 \\
\hline Total & & 196 & 5968 \\
\hline
\end{tabular}

differences observed between $32^{\circ}$ and $26^{\circ} \mathrm{S}$ also reflect the changes in penetration of low-salinity water from Río de la Plata.

\section{Temperature-Salinity Distributions}

Seasonal temperature versus salinity $(T-S)$ distributions were prepared on the basis of all hydrographic data collected over the shelf (bottom depth $<200 \mathrm{~m}$ ) that passed the quality control criteria described in section 2 (Figure 4). For clarity, in Figure 4, only samples with salinity $>30$ are included; thus the effects of continental discharge of Río de la Plata and Patos Lagoon are not fully observed. For reference, the open ocean $T-S$ characteristics are also shown schematically in Figure 4. These are representative of the major upper ocean water masses advected into the region by the Brazil and Malvinas Currents and, in Figure 4, are indicated as A and B, respectively. The warmest, shallower water within the southward flowing Brazil Current is the Tropical Water (TW), with temperature and salinity higher than $18.5^{\circ} \mathrm{C}$ and 36 [Campos et al., 1995], found immediately above the SACW.

Although there is a large variability in $T-S$ space, two welldefined water masses emerge in every season: one relatively warm and salty $(S>34.5)$ and another relatively cold and fresh $(S<34.0)$. The warm, salty shelf water is characteristic of the northern part of the region, while the cold, fresh shelf water is typical of the southern part of the region. In the middle shelf the transition between these water masses is located in the vicinity of $33^{\circ} \mathrm{S}$. Since the data are relatively evenly distributed over the shelf (Figure 1), a relatively narrow transition zone or front must exist between the water masses. In section 5 we will discuss the transition zone in detail.

In summer, two varieties of warm $\left(T>15^{\circ} \mathrm{C}\right)$ and salty $(S>34.5)$ shelf water are observed (Figure 4a). At $\sigma_{T}>24.5$ $\mathrm{kg} / \mathrm{m}^{3}$ the saltiest variety closely follows the open ocean TWSACW transition. Throughout the year this water mass is found in the outer shelf, where the bottom is deeper than 90 $\mathrm{m}$. The less salty variety is isohaline $(S \sim 35.5)$ in the $\sigma_{T}$ range between 23.5 and $26 \mathrm{~kg} / \mathrm{m}^{3}$ and occupies the inner shelf, where the bottom is shallower than $50 \mathrm{~m}$. We refer to this water mass as Subtropical Shelf Water (STSW). In T-S space the summer northern shelf water masses converge at a point close to $17^{\circ} \mathrm{C}, 35.5$, and water colder than $17^{\circ} \mathrm{C}$ falls again close to the SACW characteristics. In winter the warmest surface temperatures observed in the northern shelf decrease on average to values of $\sim 23^{\circ} \mathrm{C}$, and it is more difficult to identify the STSW from the SACW. The winter northern shelf $T-S$ distribution appears to be a product of cooling of the upper layer, with little change in salinity. The decreased surface temperature of the upper layer leads to a decreased vertical stratification. Water less dense than $24.5 \mathrm{~kg} / \mathrm{m}^{3}$ is frequently associated with a low-salinity layer, which is referred to as Coastal Water (CW) [see Castro and Miranda, 1998].

The coldest and densest northern shelf waters are found north of $23^{\circ} \mathrm{S}$ in the South Brazil Bight. This water falls well within the pure SACW $T-S$ characteristics and is associated with the intrusion of SACW (line A in Figure 4 [see Matsuura, 1996; Castro and Miranda, 1998]). In winter the cold $\left(T \sim 10.5^{\circ} \mathrm{C}\right)$ and dense $\left(\sigma_{T} \sim 26.8 \mathrm{~kg} / \mathrm{m}^{3}\right)$ water occupies the middle and outer shelf (where depth $>70 \mathrm{~m}$ ). Winter water onshore from the $70 \mathrm{~m}$ isobath is generally warmer than $16^{\circ} \mathrm{C}$. In summer the coldest SACW observed in the South Brazil Bight is warmer than $13.5^{\circ} \mathrm{C}$ but, in contrast with the winter situation, extends to shallower waters beyond the $40 \mathrm{~m}$ isobath. Thus significant seasonal differences in characteristics and extension of the SACW intrusion, in agreement with the results of Castro et al. [1987] and Campos et al. [1995], are suggested.

The cold, fresh variety of shelf water is located, on average, south of $33^{\circ} \mathrm{S}$. Except for the low-salinity surface layer, this water mass is characterized by a rather uniform salinity, averaging $\sim 33.85$ (Figure 4). The $T-S$ distribution of open ocean subantarctic water, advected northward with the Malvinas Current, is indicated as line B in Figure 4. In contrast to the northern shelf, the southern shelf $T-S$ distribution is always less salty than the water within the open ocean boundary current. Thus an intrusion of open ocean water is not observed in the south. Only near the $200 \mathrm{~m}$ isobath is there a narrow band where mixing of outer shelf bottom water and slope water causes a relative salinity minimum $(S<34)$ within the $5^{\circ}$ to $7^{\circ} \mathrm{C}$ temperature range. As shown in section 3 , the southern shelf water undergoes large seasonal changes in sea surface temperature, from $\sim 20^{\circ} \mathrm{C}$ in summer to $<10^{\circ} \mathrm{C}$ in winter (Table 2). Associated with the seasonal variation in SST is a large change in the vertical stratification, from strongly stratified summer conditions to weakly stratified or homogeneous win- 


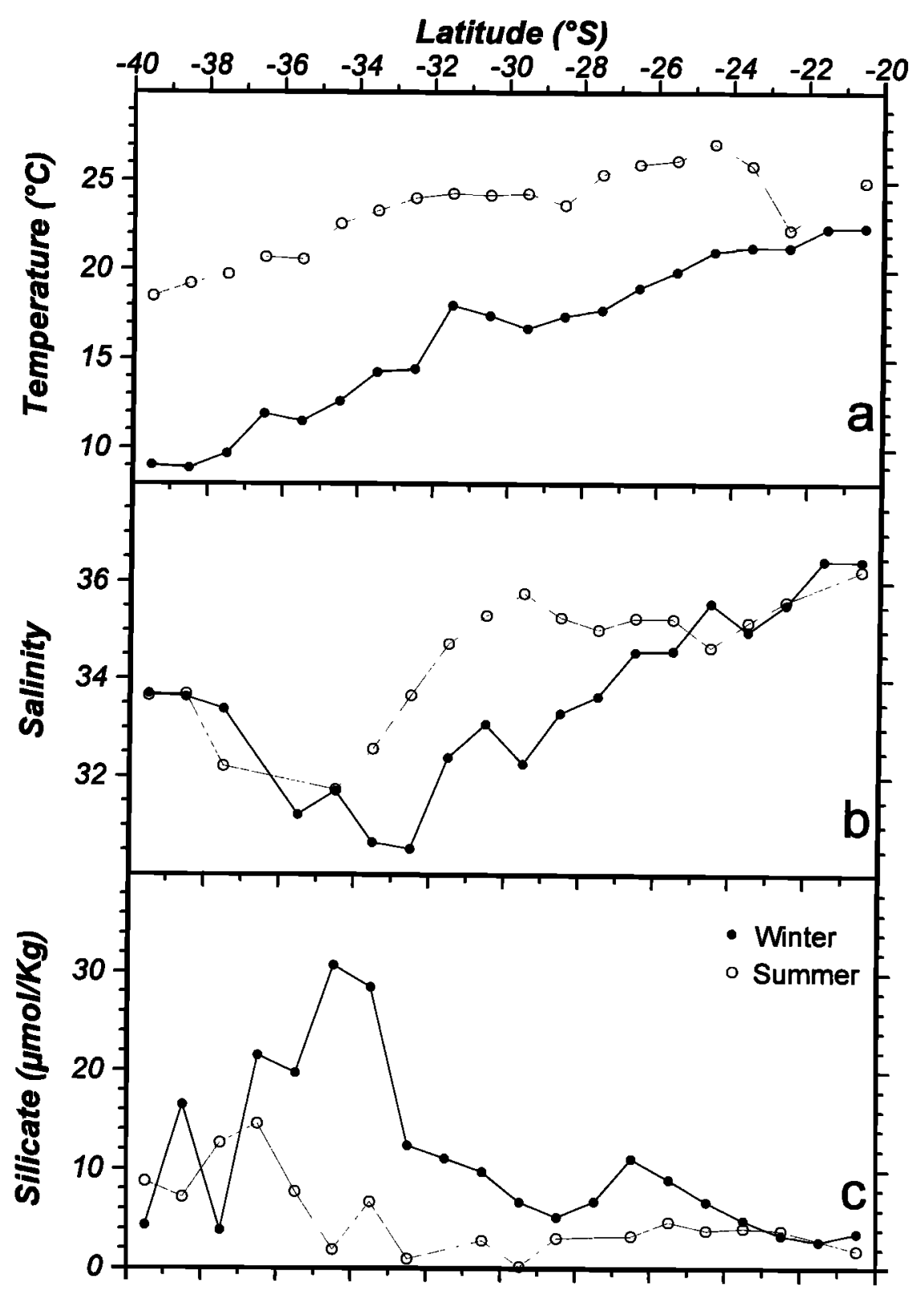

Figure 2. Meridional distribution of (a) temperature, (b) salinity, and (c) silicate averaged over $1^{\circ}$ latitude bands. Only data collected over the continental shelf are included.

ter conditions. In summer the surface water density decreases to $\sigma_{T} \sim 23.5 \mathrm{~kg} / \mathrm{m}^{3}$, and an intense thermocline is observed [Guerrero and Piola, 1997]. In winter the surface density increases to $\sigma_{T} \sim 25.5 \mathrm{~kg} / \mathrm{m}^{3}$. Given the $T-S$ distribution and stratification characteristics, we refer to the southern shelf water mass as Subantarctic Shelf Water (SASW). The coldest $\left(T \sim 5.1^{\circ} \mathrm{C}\right)$ and densest $\left(\sigma_{T} \sim 26.8 \mathrm{~kg} / \mathrm{m}^{3}\right)$ variety of SASW is found in the outer shelf at the bottom in summer and fall and throughout the water column in winter and spring. This nearbottom shelf water has density similar to the densest SACW found at the bottom in the outer shelf in the north but is substantially colder and less salty. At $\sigma_{T}>26.0 \mathrm{~kg} / \mathrm{m}^{3}$ an increase in salinity from 33.65 at $9^{\circ} \mathrm{C}$ to 34.05 at $5.1^{\circ} \mathrm{C}$ in the SASW is evident mostly in the winter data. This inflection in $T-S$ space marks the limited influence of open ocean Subantarctic Water which is characteristic of the outer shelf south of $35^{\circ} \mathrm{S}$ [see
Piola and Gordon, 1989]. As pointed out above, very few observations lie between the bulk of STSW-SACW and SASW.

North of $37^{\circ} \mathrm{S}$, the SASW is capped by low-salinity water from Río de la Plata. The Río de la Plata and the Patos-Mirim outflows also undergo large seasonal temperature changes, which are apparent in Figure 4. The Río de la Plata surface temperature ranges from $>20^{\circ} \mathrm{C}$ in summer to $<11^{\circ} \mathrm{C}$ in winter [see Guerrero et al., 1997a, b]. In winter the Río de la Plata water marks the coldest variety of diluted inner shelf water found in the region south of $35^{\circ} \mathrm{S}$. The Patos-Mirim outflow surface temperature varies between $\sim 24^{\circ}$ in summer and $\sim 13.5^{\circ} \mathrm{C}$ in winter [Möller et al., 1991]. In the inner shelf (depth<50 m) between $25^{\circ}$ and $34^{\circ} \mathrm{S}$ the winter Río de la Plata and Patos outflows produce a well-defined branch in $T-S$ space along the mixing line of the STSW characteristics from 
Table 2. Summer and Winter Surface Temperature $T$, Salinity $S$, and Silicate over the continental shelf averaged over $1^{\circ}$ Latitude Bands.

\begin{tabular}{|c|c|c|c|c|c|c|c|c|c|c|c|c|}
\hline \multirow{2}{*}{$\begin{array}{l}\begin{array}{c}\text { Latitude, } \\
{ }^{\circ} \mathrm{S}\end{array} \\
39.5\end{array}$} & \multicolumn{6}{|c|}{ Summer } & \multicolumn{6}{|c|}{ Winter } \\
\hline & \multicolumn{2}{|c|}{$\begin{array}{l}T, \\
{ }^{\circ} \mathrm{C}\end{array}$} & \multicolumn{2}{|c|}{$S$} & \multicolumn{2}{|c|}{$\begin{array}{l}\text { Silicate, } \\
\mu \mathrm{mol} / \mathrm{kg}\end{array}$} & \multicolumn{2}{|c|}{$\begin{array}{l}T, \\
{ }^{\circ} \mathrm{C}\end{array}$} & \multicolumn{2}{|c|}{$S$} & \multicolumn{2}{|c|}{$\begin{array}{l}\text { Silicate, } \\
\mu \mathrm{mol} / \mathrm{kg}\end{array}$} \\
\hline $\begin{array}{l}39.5 \\
38.5 \\
37.5 \\
36.5 \\
35.5 \\
34.5 \\
33.5 \\
32.5 \\
31.5 \\
30.5 \\
29.5 \\
28.5 \\
27.5 \\
26.5 \\
25.5 \\
24.5 \\
23.5 \\
22.5 \\
21.5 \\
20.5\end{array}$ & $\begin{array}{l}18.50 \\
19.22 \\
19.75 \\
20.70 \\
20.58 \\
22.61 \\
23.34 \\
24.04 \\
24.31 \\
24.22 \\
24.31 \\
23.67 \\
25.40 \\
25.98 \\
26.20 \\
27.16 \\
25.93 \\
22.32 \\
\\
25.01\end{array}$ & $\begin{array}{l}(0.99) \\
(1.04) \\
(1.68) \\
(1.03) \\
(0.79) \\
(0.84) \\
(0.71) \\
(0.53) \\
(0.66) \\
(0.90) \\
(0.66) \\
(1.86) \\
(0.33) \\
(0.67) \\
(0.93) \\
(1.36) \\
(1.78) \\
(3.73) \\
(1.91)\end{array}$ & $\begin{array}{l}33.66 \\
33.69 \\
32.22 \\
25.95 \\
18.85 \\
31.75 \\
32.58 \\
33.68 \\
34.74 \\
35.32 \\
35.78 \\
35.28 \\
35.03 \\
35.27 \\
35.25 \\
34.67 \\
35.19 \\
35.62 \\
36.25\end{array}$ & $\begin{array}{l}(0.10) \\
(0.11) \\
(2.07) \\
(6.34) \\
(8.39) \\
(2.27) \\
(0.77) \\
(1.48) \\
(1.03) \\
(0.69) \\
(0.23) \\
(0.84) \\
(0.45) \\
(1.05) \\
(1.06) \\
(1.24) \\
(0.92) \\
(0.49) \\
\\
(0.07)\end{array}$ & $\begin{array}{r}8.78 \\
7.23 \\
12.68 \\
14.63 \\
7.80 \\
1.93 \\
6.80 \\
1.00 \\
\\
2.90 \\
0.22 \\
3.12 \\
\\
3.36 \\
4.79 \\
3.96 \\
4.18 \\
26.15 \\
\\
1.90\end{array}$ & $\begin{array}{r}(4.75) \\
(4.39) \\
(11.91) \\
(9.53) \\
(0.00) \\
(0.78) \\
(0.00) \\
(0.00) \\
\\
(0.00) \\
(0.06) \\
(1.45) \\
\\
(1.53) \\
(1.52) \\
(3.35) \\
(3.39) \\
(23.35) \\
\\
(0.00)\end{array}$ & $\begin{array}{r}9.05 \\
8.87 \\
9.69 \\
11.94 \\
11.53 \\
12.65 \\
14.29 \\
14.46 \\
18.04 \\
17.48 \\
16.77 \\
17.44 \\
17.79 \\
19.04 \\
19.94 \\
21.08 \\
21.32 \\
21.32 \\
22.38 \\
22.45\end{array}$ & $\begin{array}{l}(1.53) \\
(1.25) \\
(1.66) \\
(1.67) \\
(1.28) \\
(1.65) \\
(1.98) \\
(1.83) \\
(2.64) \\
(1.32) \\
(1.33) \\
(1.70) \\
(0.62) \\
(1.07) \\
(0.89) \\
(0.78) \\
(1.27) \\
(1.15) \\
(0.99) \\
(0.43)\end{array}$ & $\begin{array}{l}33.70 \\
33.63 \\
33.39 \\
25.42 \\
31.23 \\
31.72 \\
30.67 \\
30.54 \\
32.40 \\
33.09 \\
32.28 \\
33.32 \\
33.66 \\
34.57 \\
34.60 \\
35.58 \\
35.00 \\
35.55 \\
36.45 \\
36.44\end{array}$ & $\begin{array}{l}(0.15) \\
(0.20) \\
(0.83) \\
(6.90) \\
(3.59) \\
(3.64) \\
(2.88) \\
(2.52) \\
(2.74) \\
(2.26) \\
(1.71) \\
(1.59) \\
(0.97) \\
(0.93) \\
(0.96) \\
(0.77) \\
(3.95) \\
(0.81) \\
(0.44) \\
(0.36)\end{array}$ & $\begin{array}{r}4.36 \\
16.53 \\
3.89 \\
21.58 \\
19.80 \\
30.76 \\
28.55 \\
12.46 \\
11.18 \\
9.83 \\
6.82 \\
5.26 \\
6.89 \\
11.20 \\
9.10 \\
6.84 \\
4.98 \\
3.43 \\
2.83 \\
3.66\end{array}$ & $\begin{array}{r}(4.27) \\
(25.45) \\
(4.67) \\
(29.29) \\
(19.86) \\
(26.50) \\
(20.26) \\
(22.73) \\
(9.88) \\
(5.45) \\
(4.08) \\
(2.44) \\
(5.20) \\
(5.20) \\
(5.83) \\
(4.60) \\
(2.28) \\
(1.49) \\
(2.00) \\
(2.62)\end{array}$ \\
\hline
\end{tabular}

The standard deviations for each band are given in parenthesis.

$T \sim 19^{\circ}$ to $20^{\circ} \mathrm{C}$ and $S \sim 35.6$ to $T \sim 13^{\circ} \mathrm{C}$ and $S \sim 30$. Low-salinity $(S<35)$ winter water warmer than $20^{\circ} \mathrm{C}$ (e.g., warmer than the local TW) is only found in the inner shelf north of $25^{\circ} \mathrm{S}$.

\section{Subtropical Shelf Front}

On the basis of the meridional variation of sea surface temperature and the seasonal temperature-salinity distributions it is evident that below the low-salinity cap, two distinct water masses occupy the continental shelf in the region bounded by $20^{\circ}$ and $40^{\circ} \mathrm{S}$. Moreover, it is apparent that a relatively narrow transition zone or front separates these water masses. In this section we describe the transition zone.

As shown above, the freshwater discharge of Río de la Plata and Patos-Mirim Lagoon produce a widespread influence on the sea surface salinity. Large seasonal variations in sea surface temperature are also observed. Because the sharp transition between the SASW and STSW is apparent below the upper layers, we focus first on the temperature and salinity structures below the seasonal thermocline. We have chosen the $50 \mathrm{~m}$ depth layer, which is deep enough to minimize the large seasonal variability observed in the upper layers and yet includes a wide area of continental shelf.

The distribution of temperature $\left(T_{50}\right)$, salinity $\left(S_{50}\right)$, and density $\left(\sigma_{50}\right)$ at $50 \mathrm{~m}$ depth in summer and winter from all stations located between the 50 and $100 \mathrm{~m}$ isobaths is shown in Figure 5. Data farther offshore have been excluded to avoid an unwanted influence of the deep ocean regimes. South of $\sim 38^{\circ} \mathrm{S}$, most data fall below $12^{\circ} \mathrm{C}$; the few observations near $40^{\circ} \mathrm{S}$ with $T_{50} \sim 14^{\circ} \mathrm{C}$ were obtained in a region where the annual temperature cycle is high [Podestá et al., 1991] and warm anomalies are frequently observed [Piola and Rivas, 1997]. Both summer and winter temperatures increase northward, reaching $\sim 18^{\circ} \mathrm{C}$ at $33^{\circ} \mathrm{S}$ and remain relatively unchanged farther north up to $28^{\circ} \mathrm{S}$. The northward temperature increase is more abrupt (from $10.8^{\circ}$ to $18^{\circ} \mathrm{C}$ ) in winter. Although some high-temperature observations are found north of $28^{\circ} \mathrm{S}$, in summer, $T_{50}$ decreases on average to values varying between $15^{\circ}$ and $17^{\circ} \mathrm{C}$. Over the shelf between $27^{\circ}$ and $24^{\circ} \mathrm{S}, T_{50}$ is consistently $2^{\circ} \mathrm{C}$ higher in winter than in summer. This is the region where substantial intrusions of $\mathrm{SACW}$ are frequently observed [see Matsuura, 1996]. It is noted that north of $\sim 33^{\circ} \mathrm{S}$, the coldest (and densest) variety of winter surface water is found off Cabo Frio, at $23^{\circ} \mathrm{S}$. This water is virtually pure SACW that forms the branch of cold, salty water apparent in the summer and winter $T-S$ distributions at $\sigma_{T}>26$ $\mathrm{kg} / \mathrm{m}^{3}$ (Figure 4).

Between $40^{\circ}$ and $35^{\circ} \mathrm{S}$ the salinity at $50 \mathrm{~m}$ remains remarkably constant $(\sim 33.65)$ with values typical of the SASW. Between $34^{\circ}$ and $32^{\circ} \mathrm{S}, S_{50}$ increases to 35.5 , typical of the STSW. In summer, $S_{50}$ shows little variability north of $32^{\circ} \mathrm{S}$, except for the region near $23^{\circ} \mathrm{S}$, where the salinity varies between 35 and 36.5. In winter, low-salinity $(S<34)$ waters extend from $30^{\circ}$ to $26^{\circ} \mathrm{S}$. The low-salinity observations cannot be associated to northward penetration of SASW because no low-temperature observations are found in that latitude range.

The middle shelf temperature and salinity at $50 \mathrm{~m}$ suggest that a relatively narrow and intense frontal zone separates the SASW from the STSW; we refer to this feature as the Subtropical Shelf Front (STSF). On average, the front appears to be located in the vicinity of $33^{\circ} \mathrm{S}$. Because the front location and vertical and horizontal extent may have substantial variability, next we present one quasi-synoptic data set, which covers most of the shelf and western boundary currents in the area between $25^{\circ}$ and $40^{\circ} \mathrm{S}$.

From late August to mid-November 1977, the $R / V$ Almirante Saldanha occupied 201 hydrographic stations arranged in 24 vertical sections across the continental shelf and the western boundary currents (Figure 6). The cruise covers the shelf area between $25^{\circ} \mathrm{S}$ in the southern South Brazil 

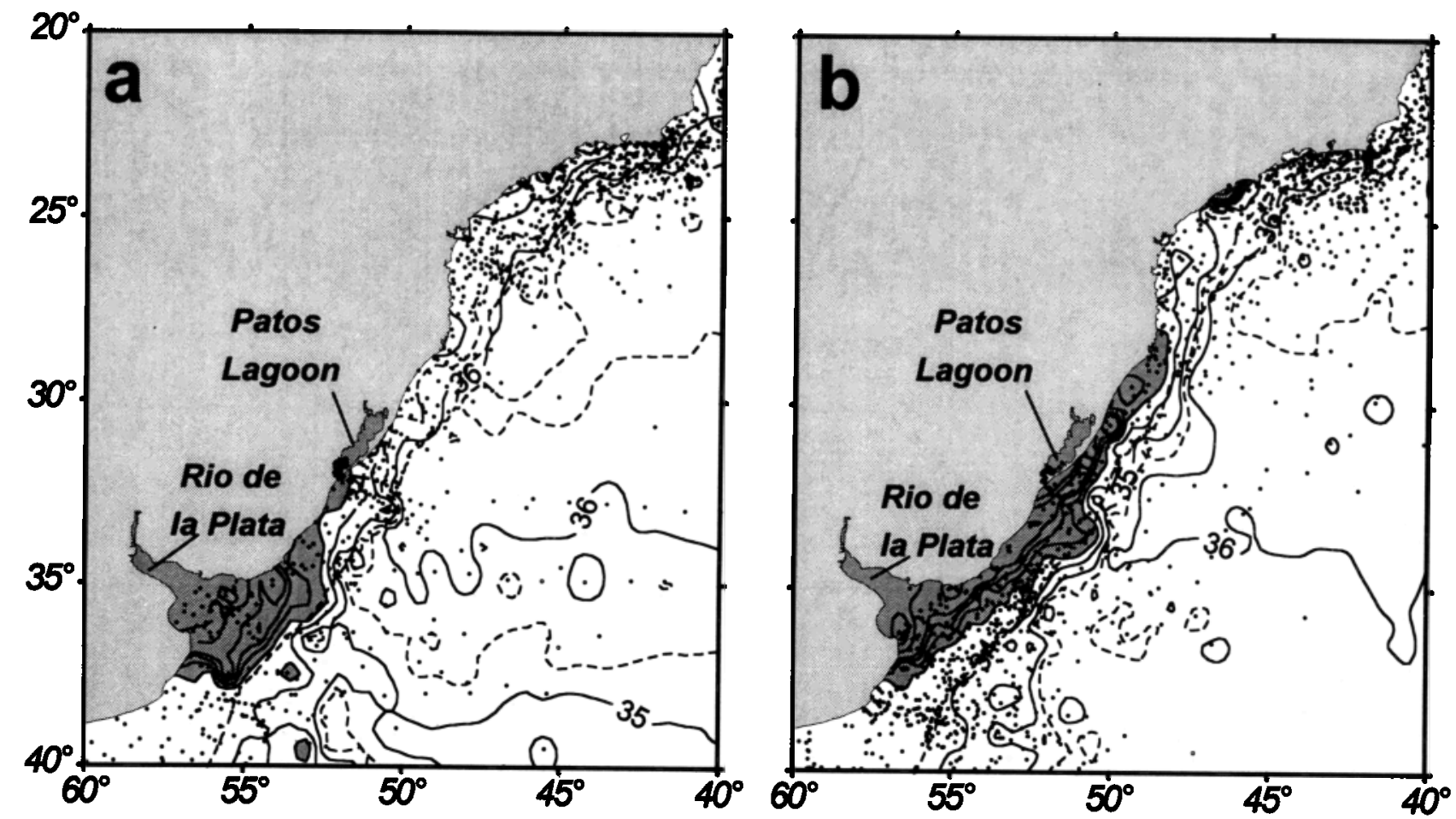

Figure 3. (a) Summer (January-March) and (b) winter (July-September) surface salinity distributions. Contour interval is 5 for $S<30$ and 1 for $S>30$, and selected contours $(S>35)$ at 0.5 are dashed. Note the northward extension of the Río de la Plata plume during winter. Dots indicate station locations. The shading indicates areas where $S<33$.

Bight and $38^{\circ} \mathrm{S}$, south of the mouth of Río de la Plata. The salinity distribution at $50 \mathrm{~m}$ depth (Figure 6) reveals a sharp salinity front separating SASW $(S<34)$ and STSW $(S>35)$. The front intersects the bottom off the mouth of Patos Lagoon at $32^{\circ} \mathrm{S}$ and is oriented in a north-south direction across the shelf and farther offshore where it marks the subsurface transition between the subantarctic and subtropical waters at the Brazil-Malvinas Confluence.

Middle shelf vertical temperature and salinity sections from $R / V$ Almirante Saldanha are shown in Figure 7. The sections were prepared from the hydrographic stations located as close as possible to the $100 \mathrm{~m}$ isobath (see Figure 6 for section location). South of $35^{\circ} 30^{\prime} \mathrm{S}$ the temperature is $<12^{\circ} \mathrm{C}$, and the thermal stratification is weak. These characteristics are typical of winter SASW (see Figure 5a). Near $34^{\circ} \mathrm{S}$ (stations 65 and 76), temperature increases to values $>15^{\circ} \mathrm{C}$ throughout the water column, marking the transition between SASW and STSW. The front location and thermohaline characteristics observed in late winter 1977 agree with the transition found in the historical data at $50 \mathrm{~m}$ depth.

The salinity section also shows a relatively uniform water mass south of $36^{\circ} \mathrm{S}$, with values ranging between 33.65 and 33.7. Near $35^{\circ} \mathrm{S}$, in the upper $30 \mathrm{~m}$ of the water column, the low-salinity plume $(S<26)$ from the Río de la Plata discharge is evident. The plume extends northward to $\sim 32^{\circ} \mathrm{S}$. Below the low-salinity layer an intense salinity front is observed. The cross-front temperature and salinity gradients at $70 \mathrm{~m}$ are $6^{\circ} \mathrm{C} / 100 \mathrm{~km}$ and $>1.5 / 100 \mathrm{~km}$, respectively. North of the STSF at depths $>30 \mathrm{~m}$, there are no salinity observations $<35$. Though large horizontal temperature and salinity gradients are associated with the STSF; below the upper layer, these gradi- ents are nearly density compensating, and no large cross-front density gradient is found (Figure 7c). The $26 \mathrm{~kg} / \mathrm{m}^{3}$ isopycnal deepens northward from the sea surface at $37^{\circ} \mathrm{S}$ to nearly 100 $\mathrm{m}$ at the STSF and rises gently farther north to reach $60 \mathrm{~m}$ in the SBB. Thus a wedge of low-density water is observed at the STSF, below the low-salinity water from Río de la Plata (Figure 7c).

The silicate section along the outer shelf (not shown) indicates near-surface values as high as $40 \mu \mathrm{mol} / \mathrm{kg}$ near $34^{\circ} \mathrm{S}$, associated to the Río de la Plata discharge. Within the SASW, south of $38^{\circ} \mathrm{S}$, silicate values vary between 4 and $7 \mu \mathrm{mol} / \mathrm{kg}$ and decrease northward to $<1 \mu \mathrm{mol} / \mathrm{kg}$. In the South Brazil Bight, silicate varies between 1 and $4 \mu \mathrm{mol} / \mathrm{kg}$, and there is a near-bottom maximum ( 7 to $12 \mu \mathrm{mol} / \mathrm{kg}$ ) associated to the winter penetration of SACW in the outer shelf.

There are substantial changes in the cross-shelf salinity structure at either side of the STSF. At $32^{\circ} \mathrm{S}$, north of the STSF (Figure 8a), the STSW is identified as a mixture of SACW penetrating to the middle shelf $(S>35)$ and the lowsalinity upper layer. At $36^{\circ} \mathrm{S}$ the SASW $(S<33.8)$ occupies most of the central and outer shelf and the low-salinity water influenced by the Río de la Plata outflow is limited to the inner shelf (Figure 8b). The temperature and salinity contrast observed across the STSF (Figure7) is highest in the 25.5 to $26 \mathrm{~kg} / \mathrm{m}^{3} \sigma_{T}$ range. At $36^{\circ} \mathrm{S}$, SASW is found within the 25.5 to $26 \mathrm{~kg} / \mathrm{m}^{3} \sigma_{T}$ interval, while north of the STSF the same density range corresponds to the much saltier $(S>36)$ subsurface layer characteristic of the Tropical Water and the outer shelf near-bottom high-salinity intrusion $(S>35)$ associated to $\mathrm{SACW}$. The cross-shelf sections clearly show that there is neither northward penetration of SASW to $32^{\circ} \mathrm{S}$ nor south- 


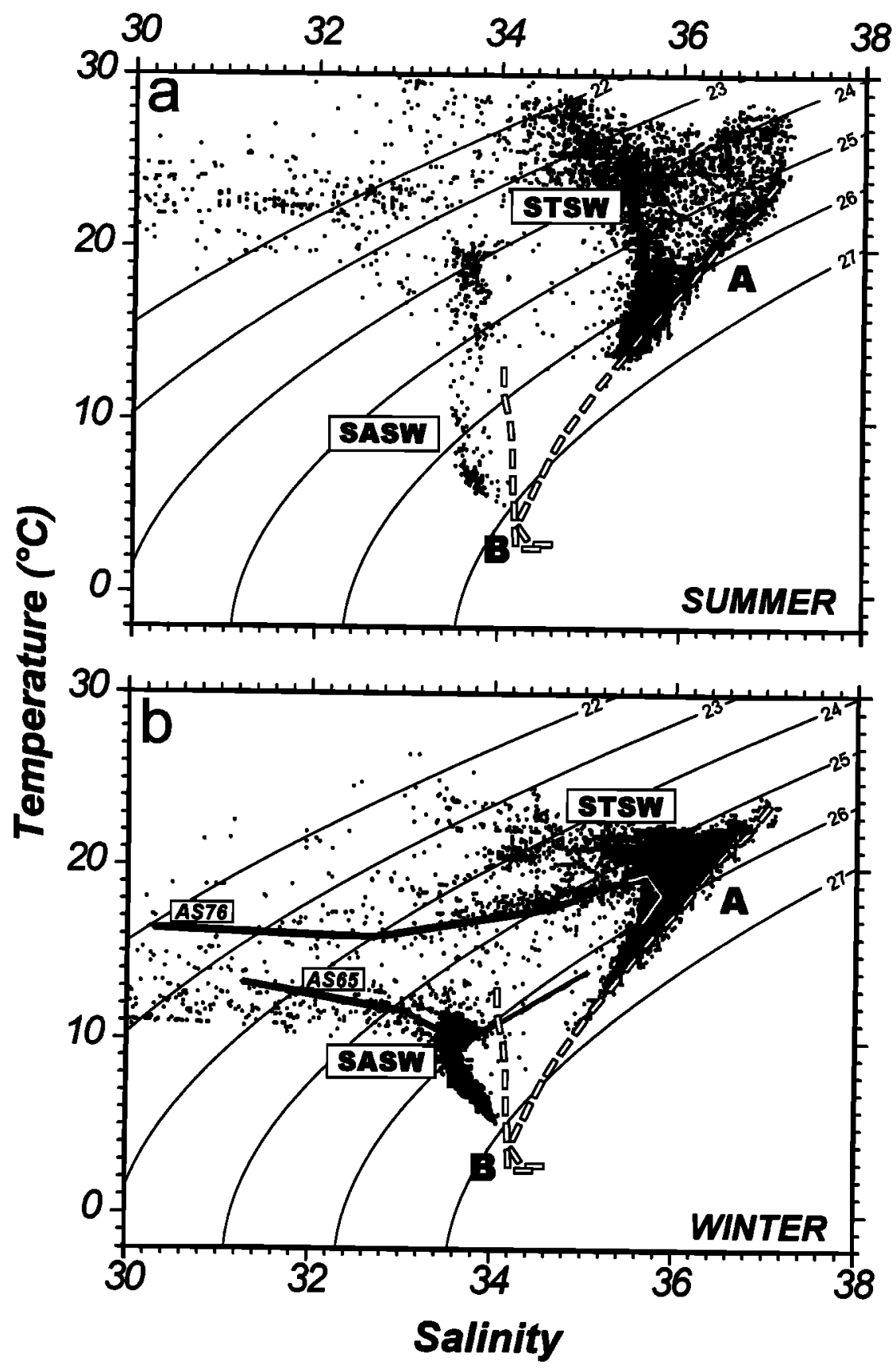

Figure 4. Temperature-salinity distribution for the shelf area where bottom depth $<200 \mathrm{~m}$. (a) Summer (January-March) and (b) winter (July-September). STSW, Subtropical Shelf Water; SASW, Subantarctic Shelf Water. Stations AS65 and AS76, collected in the vicinity of the Subtropical Shelf Front, are indicated. The mean $T-S$ distributions of the South Atlantic Central Water (A) and the Subantarctic Water (B) are shown for reference. The $\sigma_{T}$ lines are shown at $1 \mathrm{~kg} / \mathrm{m}^{3}$ intervals.

ward penetration of STSW to $36^{\circ} \mathrm{S}$. These water masses must be advected offshore at the STSF.

\section{Discussion}

The large meridional variations in subsurface water mass properties observed over the middle and outer shelf below the upper 30 to $40 \mathrm{~m}$ of the water column (Figures 5 and 6) resemble the variations observed in the open ocean across the Brazil-Malvinas Confluence. Synoptic distributions of temperature and salinity in the area (e.g., Figure 6) suggest that the location of the Subtropical Shelf Front may be linked to the point where the Brazil-Malvinas Confluence separates from the continental slope. The cross-front thermohaline gradients at the Brazil-Malvinas Confluence are associated with the convergence of water masses of the western boundary currents. Similarly, the STSF must be maintained by the convergence of the SASW and STSW. Thus, below the low-salinity layers associated with the Río de la Plata and Patos discharge the northward flow of SASW and southward flow of STSW is suggested.

The northward flow of shelf water in the region south of 


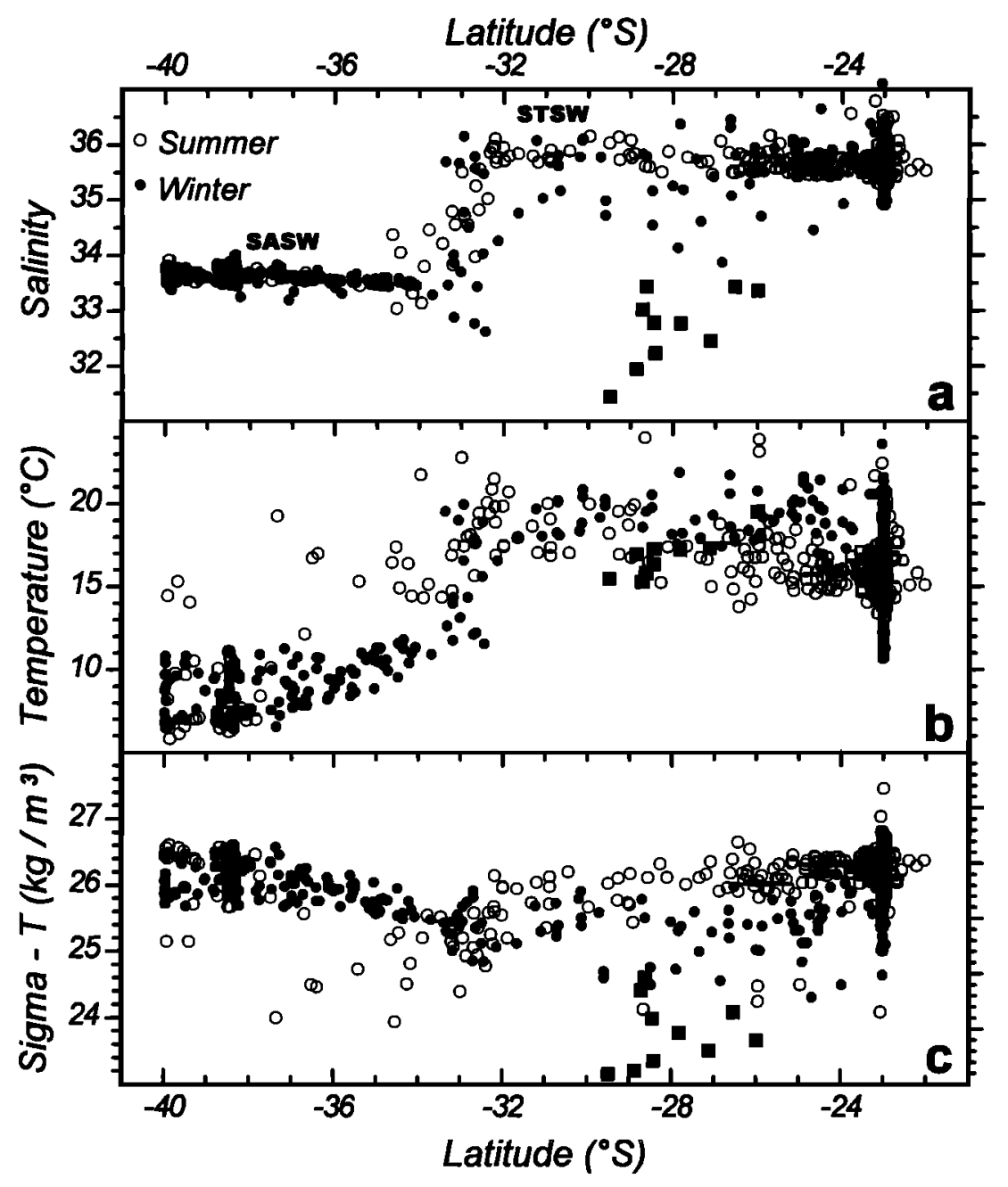

Figure 5. Alongshelf distribution of (a) salinity, (b) temperature, and (c) density anomaly at a depth of $50 \mathrm{~m}$ as a function of latitude. The squares mark the low-salinity observations near the head of the low-salinity plume. Only the data collected at stations located between the 50 and $100 \mathrm{~m}$ isobath are used. Note the sharp salinity increase from 33.6 at $34^{\circ} \mathrm{S}$ to $>35.5$ at $32^{\circ} \mathrm{S}$, marking the transition between the Subantarctic Shelf Water to the Subtropical Shelf Water.

$40^{\circ} \mathrm{S}$ has been inferred on the basis of observations and models (see Piola and Rivas [1997] for a review). However, there has been considerable debate on the direction of the mean flow between $40^{\circ} \mathrm{S}$ and the mouth of Río de la Plata. The controversy arises from the presence of subtropical plankton species in summer near shore, which has been interpreted as advection of subtropical water well south of $35^{\circ} \mathrm{S}$. Balech $[1949,1971]$ referred to the warm coastal drift, and Boltovskoy $[1970,1981]$ suggested that the observations of relatively high near-shore sea surface temperature were due in part to water from the western branch of the Brazil Current introduced over the shelf associated to local wind forcing and eddies. The intrusion of water from the Brazil Current or a southward extension of STSW should produce a rather large salinity increase in the area. However, the horizontal salinity distributions (e.g., Figures 3 and 6) and the $T-S$ distributions (Figure 4) reveal that the SASW is relatively homogeneous in salinity, not significantly different from its source farther south. Though the flow direction cannot be inferred from these distributions, we find no evidence indicating the penetration of subtropical water over the shelf south of $\sim 35^{\circ} \mathrm{S}$.
Campos et al. [1996a] and Stevenson [1996] described the trajectories of three surface drifters deployed in the Brazil Current near $24^{\circ} \mathrm{S}$ in February 1993. After drifting toward the SE for a period of 4 to 6 months, all drifters moved onshore (at different times and latitudes) and described an elongated cyclonic loop to return northward over the shelf and reach, in July, latitudes close to that of deployment. Sea surface temperature from the drifters was close to $25^{\circ} \mathrm{C}$ along the southward path over the Brazil Current and $20^{\circ} \mathrm{C}$ over the shelf. Satellite-derived sea surface temperatures reveal that the coldest water tongue over the shelf $\left(17^{\circ} \mathrm{C}\right)$ extends northward to $26^{\circ} \mathrm{S}$ [Campos et al., 1996a]. An additional drifter deployed at the Brazil Current in late April 1993 near $30^{\circ} \mathrm{S}$ also drifted onshore and followed a similar path and temperature trend, suggesting that the northward recirculation was indeed a large scale feature at the time. The path over the shelf and the relatively low sea surface temperature have been interpreted as a northward penetration of the Malvinas Current [Stevenson, 1996]. The historical winter data reveal that relatively cold surface waters $\left(T \sim 17^{\circ} \mathrm{C}\right)$ are frequently observed over the shelf and may explain the observations of 1993 [see Campos 


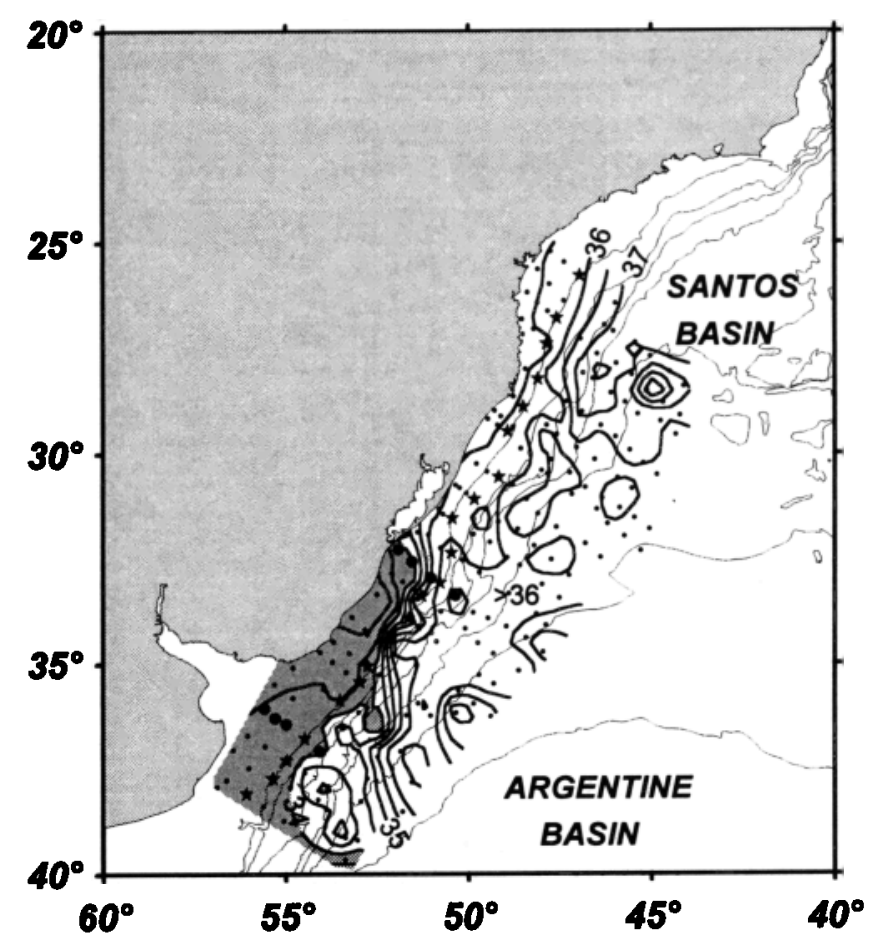

Figure 6. Salinity distribution at $50 \mathrm{~m}$ depth based on the hydrographic data collected from Almirante Saldanha betweeen late August and mid-November 1977. Small dots indicate station locations, and contour interval is 0.5 . The shading indicates areas where $S<34$. The stars indicate stations used to prepare the vertical sections of Figure 7, and the large dots indicate stations used to prepare the vertical sections of Figure 8. Thin lines are the 100, 200, 1000, 2000, 3000,4000 , and $5000 \mathrm{~m}$ isobaths.

et al., 1999]. The northward flow revealed by the surface drifters is possibly associated with the northward penetration of the winter low-temperature and low-salinity water from the Plata and Patos outflows to $27^{\circ} \mathrm{S}$ (Figure 3b).

Alternatively, the northward flow may be associated with a northward recirculation of SASW. However, on the basis of the historical temperature and salinity distributions (e.g., Figures 3 and 4), northward penetrations of SASW north of $30^{\circ} \mathrm{S}$ seem unlikely. Low sea surface salinity data $(S<33)$ collected near $25^{\circ} \mathrm{S}$ in winter 1993 [Campos et al., 1996b] suggest that the northward penetration of low surface temperature water has substantial contributions from the Río de la Plata. The climatological distribution of surface salinity (Figure $3 \mathrm{~b}$ ) shows that the northward penetration of low-salinity water is semipermanent during winter.

There are also substantial and rather abrupt morphological variations along the continental shelf, which may significantly alter the flow. South of $39^{\circ} \mathrm{S}$, the shelf width varies between 350 and $500 \mathrm{~km}$ and decreases to $<200 \mathrm{~km}$ at $37^{\circ} \mathrm{S}$. The width continues decreasing northward to $<90 \mathrm{~km}$ at $31^{\circ} \mathrm{S}$ off southern Brazil. In the South Brazil Bight, near $25^{\circ} \mathrm{S}$, the shelf widens again to $240 \mathrm{~km}$. Thus, owing to the width and depth reduction the cross-shelf area decreases northward by a factor of 4.5 , from $45 \times 10^{3} \mathrm{~km}^{2}$ near $42^{\circ} \mathrm{S}$ to $9.7 \times 10^{3} \mathrm{~km}^{2}$ at $31^{\circ} \mathrm{S}$. Consequently, either a significant increase in the velocity field or an export of shelf waters to the deep ocean basins to the east is expected north of $\sim 39^{\circ} \mathrm{S}$. Observations of low-salinity water within the core of the Brazil-Malvinas Con- fluence near $40^{\circ} \mathrm{S}$ [Gordon, 1989; Provost et al., 1995] suggest that the advection of SASW occurs at the separation point of the boundary currents from the continental margin. The intense thermohaline contrast across the STSF (Figures 4, 7 , and 8) suggests that most of the SASW and STSW are exported to the open ocean along the front.

The northward extension of the low-salinity water from the Río de la Plata outflow into the shelf off southern Brazil produces a major impact on the vertical stratification. Though winter heat loss to the atmosphere will weaken the vertical stratification and favor vertical mixing, the low-salinity cap acts to limit and may eventually prevent vertical mixing. Evidence for the cooling of the low-salinity cap is found in the winter $T-S$ distribution (Figure $4 \mathrm{~b}$ ). In the latitude range $24^{\circ}$ to $33^{\circ} \mathrm{S}$ the winter surface waters show a trend in $T-S$ space from the warm, high-salinity STSW $20^{\circ} \mathrm{C}$ at 35.5 toward $12^{\circ} \mathrm{C}$ at 30 , and a subsurface $T$ maximum $\left(T \sim 20^{\circ} \mathrm{C}\right)$ is frequently observed. Winter heat loss to the atmosphere progressively cools the surface water, but convection is limited to the layer above the halocline. For instance, the Almirante Saldanha station 76 (Figure 4b) located over the $100 \mathrm{~m}$ isobath shows a cold, low-salinity surface layer capping the warm, salty STSW. This vertical structure has been referred to as inverted thermocline [Castello and Möller, 1977]. Inner shelf observations at $30^{\circ} \mathrm{S}$ from winter 1966 show low surface temperature $\left(T=13.84^{\circ} \mathrm{C}\right)$ and salinity $(S=26.09)$ water capping mixtures of SACW, where $\left(T>17^{\circ} \mathrm{C}\right)$. Thus low sea surface temperatures observed in winter over the shelf off southern Brazil may be partly associated with the northward spreading of lowsalinity water from the Río de la Plata and Patos-Mirim Lagoon.

Between $30^{\circ}$ and $26^{\circ} \mathrm{S}$, relatively low temperature $\left(T_{50}<18^{\circ} \mathrm{C}\right)$, salinity $\left(S_{50}<34\right)$, and density $\left(\sigma_{50}<24.8 \mathrm{~kg} / \mathrm{m}^{3}\right)$ are observed at $50 \mathrm{~m}$ (Figure 5). In this area the late winter sea surface temperature is in the range $15^{\circ}$ to $17^{\circ} \mathrm{C}$, the water column is virtually isothermal, and the vertical salinity (and density) gradient is weaker than farther south, allowing some degree of vertical mixing. At $50 \mathrm{~m}$ depth the $T-S$ characteristics match the surface $T-S$ found at the vicinity of the head and the offshore edge of the low-salinity plume, suggesting that the low-salinity observations are associated to subduction or isopycnal mixing from the plume's edge. This is confirmed by the observation of vertically homogeneous water columns at the edge of the low-salinity plume in winter 1962. Thus, north of $34^{\circ} \mathrm{S}$, the vertical extent of winter convection will strongly depend on the spreading of low-salinity waters over the shelf.

To evaluate the possible effect of seasonal changes in the salinity distribution over the shelf, a simple mass and salt balance is used. The mean freshwater imbalance through the sea surface is small throughout the region [Baumgartner and Reichel, 1975; Höflich, 1984] and is therefore neglected in this analysis. The SASW salinity upstream from the Río de la Plata is 33.65 ; thus all water with salinity $<33.65$ must be a product of dilution by the continental discharge. The mean volumes of water fresher than 33.65 in summer and winter are $3.24 \times 10^{3}$ and $3.89 \times 10^{3} \mathrm{~km}^{3}$, respectively, and the averaged salinity within that layer is 30.336 in summer and 30.389 in winter. On the basis of model estimates [Forbes and Garraffo, 1988] the input (northward) transport of SASW is set to $0.97 \times 10^{6} \mathrm{~m}^{3} / \mathrm{s}$ in summer and $1.26 \times 10^{6} \mathrm{~m}^{3} / \mathrm{s}$ in winter. The Paraná discharge regime has undergone rather large interannual and interdecadal variations [Garcia and Vargas, 

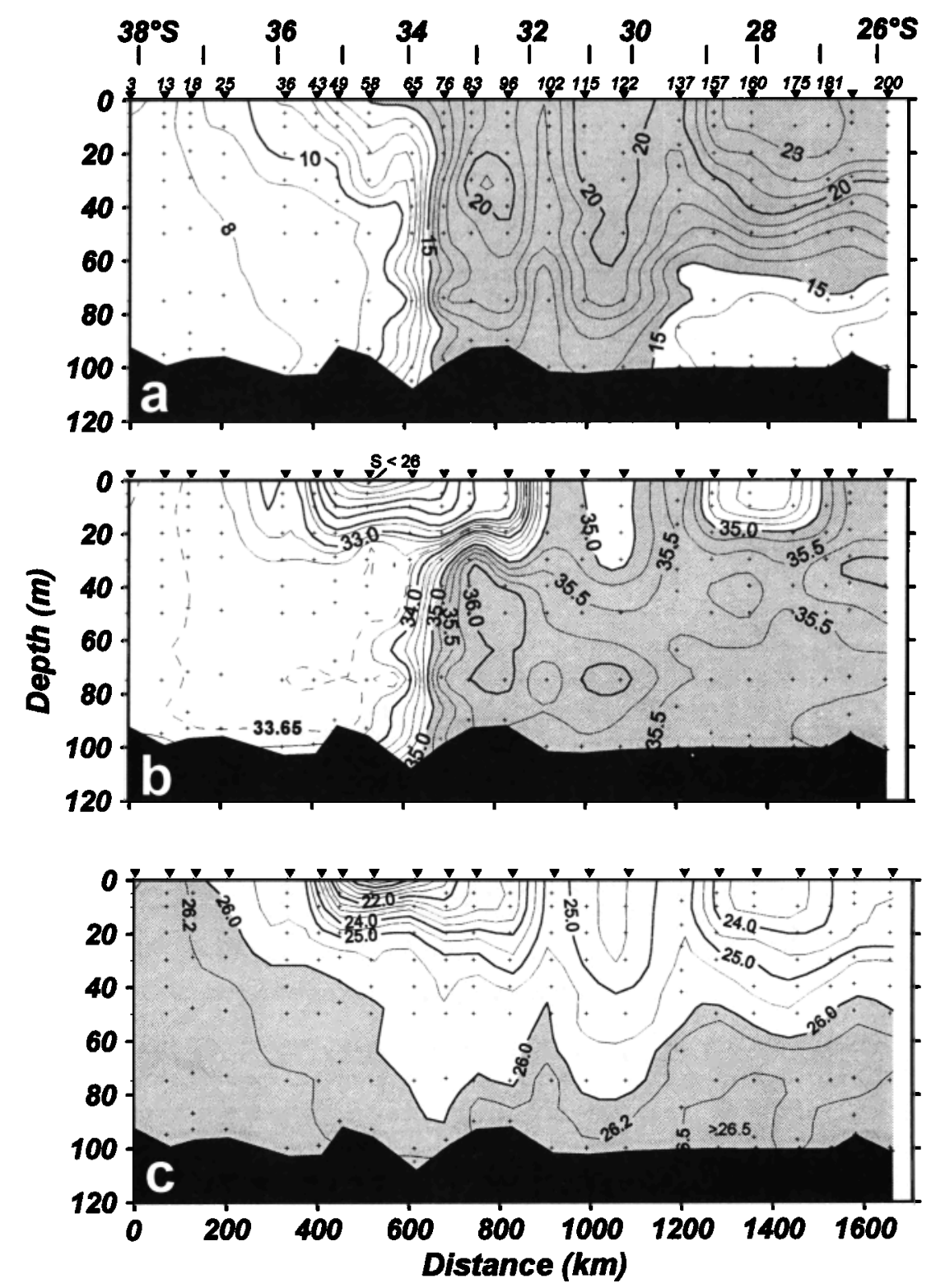

Figure 7. Alongshelf vertical sections of (a) temperature, (b) salinity, and (c) density anomaly $\left(\sigma_{T}\right)$ from data collected from $R / V$ Almirante Saldanha in winter 1977. The section was prepared using stations close to the $100 \mathrm{~m}$ isobath; see Figure 6 for station locations. Dots indicate water sample locations. Temperatures higher than $15^{\circ} \mathrm{C}$ and salinities higher than 35 are shaded to mark the STSW.

1998]. Here we calculated the Río de la Plata seasonal discharge based on 25 year-long monthly means of the Paraná and Uruguay rivers from the period between January 1973 and December 1997. From these data the mean freshwater discharge is $21.6 \times 10^{3} \mathrm{~m}^{3} / \mathrm{s}$ in summer and $23.2 \times 10^{3} \mathrm{~m}^{3} / \mathrm{s}$ in winter. On the basis of mass and salt conservation the volume transport of diluted waters (above the 33.65 isohaline) is $0.22 \times 10^{6} \mathrm{~m}^{3} / \mathrm{s}$ in summer and $0.24 \times 10^{6} \mathrm{~m}^{3} / \mathrm{s}$ in winter. The transport estimates of the low-salinity water lead to mean residence times over the shelf of 6.2 months in summer and 5.6 months in winter. These estimates must be regarded as a first approximation because freshwater imbalances through the sea surface and vertical mixing across the 33.65 isohaline have been neglected.

The Parana River, which is the major contributor to the Rio de la Plata, shows highly coherent variability at a 30 month period with equatorial Pacific sea surface temperature anomalies, associated to El Niño-Southern Oscillation (ENSO) [Depetris et al., 1996]. During intense events outflow values $>50 \times 10^{3} \mathrm{~m}^{3} / \mathrm{s}$ have been recorded. In May and July 1983, June 1992, and November 1997 the Río de la Plata monthly averaged outflow increased sharply from its average of $\sim 23 \times 10^{3}$ to $>40 \times 10^{3} \mathrm{~m}^{3} / \mathrm{s}$. In response to the Río de la Plata increased outflow associated with the 1982-1983 ENSO event, in late April and May 1983, the 30 isohaline extended $\sim 150 \mathrm{~km}$ offshore and $200 \mathrm{~km}$ along the coast of Uruguay beyond its average position (R. Guerrero, personal communication, 1998). Similar effects of increased discharge from the Patos Lagoon on the salinity distribution have been observed during the 1987 ENSO [Ciotti et al., 1995; Lima et al., 1996]. Wintertime cold sea surface temperature anomalies observed over the shelf, coherent with ENSO, have recently been re- 


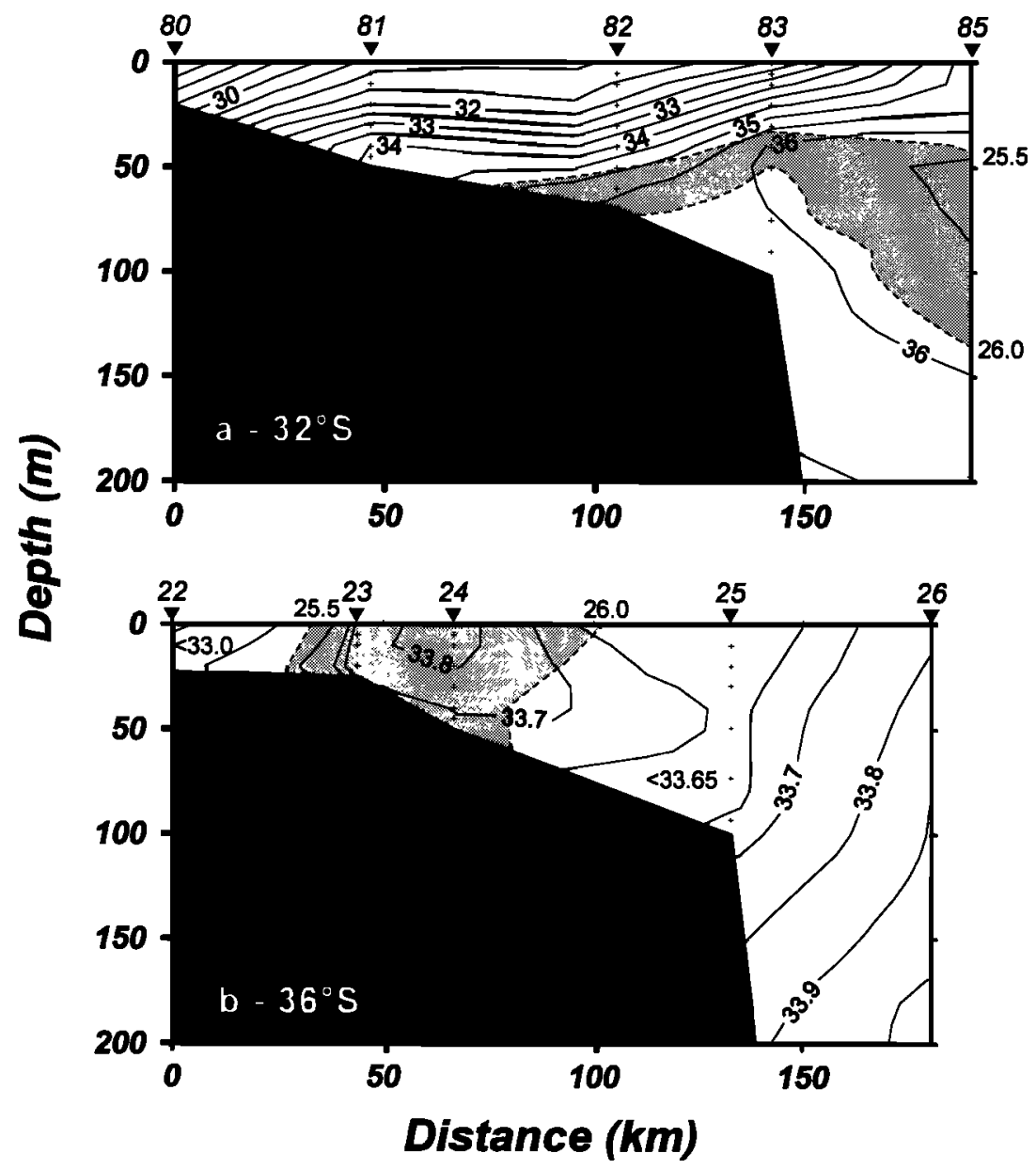

Figure 8. Cross-shelf vertical salinity sections near (a) $32^{\circ} \mathrm{S}$ and (b) $36^{\circ} \mathrm{S}$ from data collected during winter 1977 from $R / V$ Almirante Saldanha. The station positions are indicated in Figure 6 . The shaded areas indicate the 25.5 to $26.0 \mathrm{~kg} / \mathrm{m}^{3} \sigma_{T}$.

ported [Campos et al., 1999]. The displacement of isohalines associated with the river discharge variability is likely to produce, locally, a significant impact on the vertical stratification. When the discharge from Río de la Plata and the Patos Lagoon increase in phase, the latter enhances the low-salinity plume. Numerical simulations [Kourafalou et al., 1996] predict the increased river discharge should produce an extension of the coastal low-salinity tongue and of the cross-shelf lowsalinity bulge. The seasonal change in the extent of the low surface salinity reported here is of the order of 800 to 1000 $\mathrm{km}$, a factor of 5 larger than the changes observed during the 1983 large discharge event. It is possible that the increase in the offshore extension of the low-salinity water near the river mouth reaches the continental margin, is embedded in the core of the Brazil-Malvinas Confluence, and contributes to the low-surface salinity filaments observed by Gordon [1989]. Thus the seasonal variability, presumably associated to changes in the wind stress, appears to have a wider impact on the extent of the low-salinity water and on the stratification over the shelf than the large interannual discharge variability. Unfortunately, the relatively sparse surface salinity observations preclude a quantitative comparison with the river discharge and circulation variability beyond the seasonal timescale.

\section{Summary and Conclusions}

The historical hydrographic data available over the continental shelf off eastern South America reveal that in the upper layer, there is a widespread influence of the continental discharge, primarily from Río de la Plata $\left(34^{\circ} \mathrm{S}\right)$ and, locally, from Patos Lagoon $\left(32^{\circ} \mathrm{S}\right)$. During the austral winter the lowsalinity plume $(S<33)$ reaches $28^{\circ} \mathrm{S}$, while in summer it is constrained to south of $32^{\circ} \mathrm{S}$. The seasonal variability of the alongshore extent of the low-salinity plume, presumably induced by variations in the wind stress, is larger than the changes induced by the river discharge variability.

A sharp contrast in water mass characteristics exists below the low-salinity plume. The relatively cold, fresh Subantarctic Shelf Water dominates south of $\sim 33^{\circ} \mathrm{S}$, while warm, salty Subtropical Shelf Water extends primarily north of that latitude. These water masses are separated by a relatively narrow frontal zone referred to as the Subtropical Shelf Front. The front runs approximately in a meridional direction and, due to its position and thermohaline characteristics, appears as an extension of the Brazil-Malvinas Confluence (Figure 6).

The separation of the Brazil-Malvinas Confluence from the continental margin presents considerable meridional fluctuations [Olson et al., 1988; Provost et al., 1992]. Part of the 
variability appears to be associated with the annual cycle, northward penetrations of the Malvinas Current up to $33^{\circ} \mathrm{S}$ in winter, and southward penetrations of the Brazil Current in summer [Olson et al., 1988; Garzoli and Garraffo, 1989; Matano, 1993; Matano et al., 1993]. Theoretical studies suggest that meridional excursions of the separation point are related to imbalances of the transports of the colliding western boundary currents [Agra and Nof, 1993; Lebedev and Nof, 1996]. It is uncertain whether such variability is due to Malvinas Current variability or to the strength of the South Atlantic anticyclonic circulation [Matano, 1993; Garzoli and Giulivi, 1994; Smith et al., 1994], though high Brazil Current transport events $\left(\sim 40 \times 10^{-6} \mathrm{~m}^{3} / \mathrm{s}\right)$ seem to correspond to extreme southward penetrations [Goni et al., 1996]. Because the STSF appears as an extension of the Brazil-Malvinas Confluence over the continental shelf, it is possible that it also presents significant spatial fluctuations correlated to BrazilMalvinas Confluence displacements. Although the thermohaline changes across the STSF are large, the frontal fluctuations are difficult to detect from the historical hydrographic data used in this study. Moreover, because the upper layer dynamics must be linked to the plume of low-salinity water, which controls the upper layer density field and which also undergoes large seasonal fluctuations, variations of the STSF may not be readily detectable based on satellite observations. It is therefore suggested that a more complete understanding of the dynamics and variability of the STSF structure will require a combination of modeling and observations.

Acknowledgments. This work was possible through partial funding received from the Inter-American Institute for Global Change Research and grant 96/4060-0 from Fundação de Amparo à Pesquisa do Estado de São Paulo, Brazil. We benefited from discussions with J. Borus regarding the calculation and fluctuations of Río de la Plata discharge. Comments from R. Guerrero, C. Odebrecht, and two anonymous reviewers on an earlier draft of the manuscript were most helpful.

\section{References}

Agra, C., and D. Nof, Collision and separation of boundary currents, Deep Sea Res., 40, 2259-2282, 1993.

Bakum, A., and R.H.Parrish, Comparative studies of coastal pelagic fish reproductive habitats: The Brazilian sardine (Sardinella aurita), J. Cons. Int. Explor. Mer., 46, 269-283, 1990.

Bakum, A., and R.H.Parrish. Comparative studies of coastal pelagic fish reproductive habitats: The anchovy (Engraulis anchoita) of the southwestern Atlantic, ICES J. Mar. Sci., 48, 343-361, 1991.

Balech, E., Estudio crítico de las corrientes marinas, Physis, 20, 159-164, 1949.

Balech, E., Notas históricas y críticas de la oceanografía biológica argentina, $H-1027,57$ pp., Serv. Hidrografia Nav., Buenos Aires, 1971.

Baumgartner, A. and E. Reichel, The World Water Balance, 179 pp., Elsevier Sci., New York, 1975.

Boltovskoy, E., Masas de agua (característica, distribución, movimientos) en la superficie del Atlántico Sudoeste, según indicadores biológicos, H-643, 99 pp., Serv. Hidrografia. Nav., Buenos Aires, 1970.

Boltovskoy, E., Masas de agua en el Atlántico Sudoccidental, in Atlas del Zooplankton del Atlántico Sudoccidental, edited by D. Boltovskoy, 227-237 pp., Inst. Nac. Inv. Des. Pesquero, Mar del Plata, Argentina, 1981.

Brandhorst, W., and J.P. Castello, Evaluación de los recursos de anchoita (Engraulis anchoita) frente a la Argentina y Uruguay, I, Las condiciones oceanográficas, sinopsis del conocimiento actual sobre la anchoíta y el plan para su evaluación, Proy. Des. Pesq. Publ. 29, 63 pp., Food and Agric. Org., Rome, 1971.

Bunker, A.J., and R.A. Goldsmith, Archived time-series of Atlantic
Ocean meteorological variables and surface fluxes, Tech. Rep., WHOI 79-3, pp. 1-29, Woods Hole Oceanogr. Inst., Woods Hole, Mass., 1979.

Campos, E.J.D., J.E. Gonçalves, and Y. lkeda, Water mass characteristics and geostrophic circulation in the South Brazil Bight: Summer of 1991, J. Geophys. Res., I00, 18,537-18,550, 1995.

Campos, E.J.D., Y. Ikeda, B.M. Castro, S.A. Gaeta, J.A. Lorenzzetti, and M.R. Stevenson, Experiment studies circulation in the western South Atlantic, Eos Trans. $A G U, 77,(27), 253-259,1996 \mathrm{a}$.

Campos, E.J.D., J.A. Lorenzzetti, M.R.Stevenson, J.L. Stech, and R.B. de Souza, Penetration of waters from the Brazil-Malvinas Confluence region along the South American continental shelf up to $28^{\circ} \mathrm{S}$, Ann Acad. Bras. Cienc., 68, suppl. 1, 49-58, $1996 \mathrm{~b}$.

Campos, E.J.D., C. Lentini, J. Miller, and A.R. Piola, Interannual variability of the sea surface temperature in the South Brazil Bight, Geophys. Res. Lett., 26, 2061-2064, 1999.

Castello, J.P., and O.O. Möller Jr, Sobre as condiçð̃es oceanográficas no Rio Grande do Sul, Atlântica, 2, 25-110, 1977.

Castro, B.M., L.B. Miranda, and S.Y. Miyao, Condiç̃es oceanográficas na plataforma continental ao largo de Ubatuba: Variaçðes sazonais e em média escala, Bol. Inst. Oceanogr. Univ. São Paulo, 35, 135-151, 1987.

Castro, B.M., and L.B. Miranda, Physical oceanography of the western Atlantic continental shelf located between $4^{\circ} \mathrm{N}$ and $34^{\circ} \mathrm{S}$, in The Sea, vol. 11, edited by A.R. Robinson and K.H. Brink, chap. 8, pp. 209-251, John Wiley, New York, 1998.

Ciotti, A.M., C. Odebrecht, G.Fillmann, and O.O. Möller Jr, Freshwater outflow and Subtropical Convergence influence on phytoplankton biomass on the southern Brazilian continental shelf, Cont. Shelf Res., 15, 1737-1756, 1995.

Deacon, G.E.R., The hydrology of the Southern Ocean, Discovery Rep., 7, 171-238, 1933.

Depetris, P.J., S. Kempe, M. Latif, and W.G. Mook, ENSO controlled flooding in the Paraná River (1904-1991), Naturwissenschaften, 83, 127-129, 1996.

Forbes, M.C., and Z. Garraffo, A note on the mean seasonal transport on the Argentinian Shelf, J. Geophys. Res., 93, 2311-2319, 1988.

Framiñan, M.B., M.P. Etala, E.M. Acha, R.A. Guerrero, C.A. Lasta, and O.B. Brown, Physical characteristics and processes of the Rio de la Plata Estuary, in Estuaries of South America: Their Geomorphology and Dynamics, edited by G.M. Perillo, M.C. Piccolo, and M. Pino-Quivira, chap. 8, pp. 161-194, Springer-Verlag, New York, 1999.

García, N.O., and W.M. Vargas, The temporal variability in the Río de la Plata basin displayed by the rivers discharges, Clim. Change, 38, 359-379, 1998.

Garzoli, S.L., and Z. Garraffo, Transport, frontal motions and eddies at the Brazil-Malvinas Confluence, Deep Sea Res., Part A, 36, 671-703, 1989.

Garzoli, S.L., and C.F. Giulivi, What forces the variability of the southwestern Atlantic boundary currents?, Deep Sea Res., Part I, $41,1527-1550,1994$.

Glorioso, P.D., and R.A. Flather, A barotropic model of the currents off SE South America, J. Geophys. Res., I00, 13,427-13,440, 1995.

Goni, G., S. Kamholz, S. Garzoli, and D. Olson, Dynamics of the Brazil-Malvinas Confluence based on inverted echo sounders and altimetry, J. Geophys. Res., 101, 16,273-16,289, 1996.

Gordon, A.L., Brazil-Malvinas Confluence-1984, Deep Sea Res., Part A, 36, 359-384, 1989.

Guerrero, R.A., and A.R. Piola, Masas de agua en la plataforma continental, in El mar Argentino y sus Recursos Pesqueros, vol. 1, edited by E.E. Boschi, pp. 107-118, Inst. Nac. de Invest. y Desarrollo Pesquero, Mar del Plata, Argentina, 1997.

Guerrero, R.A., E.M. Acha, M.B. Framiñan, and C.A. Lasta, Physical oceanography of the Río de la Plata Estuary, Cont. Shelf Res., 17, 727-742, 1997a.

Guerrero, R.A., C.A. Lasta, E.M. Acha, H.W. Mianzan, and M.B. Framiñan, Atlas Hidrográfico del Río de la Plata, 109pp., Comisión Admin. del Río de la Plata, Inst. Nac. de Invest. y Desarrollo Pesquero, Buenos Aires, 1997b.

Hellerman, S., and M.Rosenstein, Normal monthly wind stress over the world ocean with error estimates, J. Phys. Oceanogr., 13, 1093-1104, 1983.

Höflich, O., Climate of the South Atlantic, in Climates of the Oceans, World Surv. of Climatol., vol. 15, edited by H. Van Loon, pp. 1-132, Elsevier Sci., New York, 1984. 
Kourafalou, V.H., L-Y Oey, J.D. Wang, and T.N. Lee, The fate of river discharge on the continental shelf, 1, Modeling the river plume and the inner shelf coastal current, J. Geophys. Res., 10I, 3415-3434, 1996.

Krepper, C.M., Difusión del agua proveniente del Estrecho de Magallanes en las aguas de la plataforma continental, Acta Oceanogr. Argent., I, 49-65, 1977.

Lebedev, I., and D. Nof, The drifting confluence zone, J. Phys. Oceanogr., 26, 2429-2448, 1996.

Lima, I.D., C.A.E. García, and O.O. Möller Jr, Ocean surface processes on the southern Brazilian shelf: Characterization and seasonal variability, Cont. Shelf Res., 16, 1307-1317, 1996.

Lusquiños, A.J., Algunas características de las aguas de la plataforma continental Argentina, in Datos y resultados de las campañas Pesqueria, edited by S.F. Villanueva, Pesqueria X, Publ. 10/X, Proyecto de Desarrollo Pesquero, Ser. de Inf. Técnicos, Mar del Plata, Argentina, 1971

Lusquiños, A.J., and A.G. Schrott, Corrientes en el Mar Epicontinental Argentino en invierno, 74 pp., Subsecr. de Estado de Cienc. y Técnica, Programa Nac. de Recursos Nat. Renovables, Buenos Aires, 1983.

Lusquiños, A.J., and A.J. Valdéz, Aportes al conocimiento de las masas de agua del Atlántico Sudoccidental, $H 659,48$ pp., Serv. Hidrografia Nav., Buenos Aires, 1971.

Matano, R.P., On the separation of the Brazil Current from the coast, J. Phys. Oceanogr., 23, 79-90, 1993.

Matano, R.P., M.G. Schlax, and D.B. Chelton, Seasonal variability in the Southwestem Atlantic, J. Geophys. Res., 98, 18,027-18,035, 1993.

Matsuura, Y., A probable cause of recruitment failure of the Brazilian sardine sardinella aurita population during the 1974/75 spawning season, S. Afr. J. Mar. Sci., I7, 29-35, 1996.

Miranda, L.B., and B.M. Castro, Geostrophic flow conditions of the Brazil Current at $19^{\circ} \mathrm{S}$, Cienc. Interam., 22, 44-48, 1981.

Möller, O.O., Jr, Hydrodynamique de la Lagune dos Patos: Mesures et modelisation, D.Sc. thesis, 204 pp., Univ. Bordeaux I, Bordeaux, France, 1996.

Möller, O.O., Jr, P.S. Paim, and I.D.Soares, Facteurs et mecanismes de la circulation des eaux dans l'estuaire de la Lagune dos Patos (RS, Brasil), Bull. Inst. Geol. Bassin Aquitaine, 49, 15-21, 1991.

Olson, D.L., G.P. Podestá, R.H. Evans, and O.B. Brown, Temporal variations in the separation of the Brazil and Malvinas Currents, Deep Sea Res., Part A, 35, 1971-1990, 1988.

Pereira, C.S., Seasonal variability in the coastal circulation on the Brazilian continental shelf $\left(29^{\circ} \mathrm{S}-35^{\circ} \mathrm{S}\right)$, Cont. Shelf Res., 9, $285-$ $299,1989$.

Piola, A.R., and A.L. Gordon, Intermediate waters in the southwest South Atlantic, Deep Sea Res., Part A, 36, 1-16, 1989.

Piola, A.R., and A.L. Rivas, Corrientes en la plataforma continental, in El mar Argentino y sus Recursos Pesqueros, vol. 1, edited by E.E. Boschi, pp. 119-132, Inst. Nac. de Invest. y Desarrollo Pesquero, Mar del Plata, Argentina, 1997.

Podestá, G.P., O.B. Brown, and R.H. Evans, The annual cycle of satellite-derived sea surface temperature in the southwestern Atlantic Ocean, J. Clim., 4, 457-467, 1991.

Provost, C., O. Garcia, and V. Garçon, Analysis of satellite sea surface temperature time series in the Brazil-Malvinas current confluence region: Dominance of the annual and semiannual periods, $J$ Geophys. Res., 97, 17,841-17,858, 1992.

Provost, C., S. Gana, V. Garçon, K. Maamaatuaiahutapu, and M. England, Hydrographic conditions in the Brazil-Malvinas Confluence during austral summer 1990, J. Geophys. Res., I00, 10,655$10,678,1995$.

Rivas, A.L., Current meter observations in the Argentine Continental Shelf, Cont. Shelf Res., 17, 391-406, 1997.

Rivas, A.L., and A. Frank Langer, Mass and heat transport in the Argentinian Continental Shelf, Cont. Shelf Res., 16, 1283-1295, 1996.

Smith, L.T., E.P. Chassignet, and D.B. Olson, Wind forced variations in the Brazil-Malvinas confluence region as simulated in a coarse resolution numerical model of the South Atlantic, J. Geophys. Res., 99, 5095-5117, 1994.

Stevenson, M.R., Recirculation of the Brazil Current south of $23^{\circ} \mathrm{S}$, Int. WOCE Newsl., 22, 30-32, 1996.

United Nations Educational, Scientific, and Cultural Organization (UNESCO), Global river discharge data base, in International Hydrological Programme, vol. V, South America, 123 pp., Paris, 1996.

Zavialov, P.O., R.D. Ghisolfi, and C.A.E. Garcia, An inverse model for seasonal circulation over the South Brazilian Shelf: Near-surface velocity from the heat budget, $J$ Phys. Oceanogr., 28,545 562,1998

E.J.D. Campos, Instituto Oceanográfico, Universidade de São Paulo, São Paulo, SP 05508-900, Brazil

M. Charo and A.R. Piola, Departameto Oceanografia, Servicio de Hidrografia Naval, Av. Montes de Oca 2124, 1271 Buenos Aires, Argentina. (apiola@rina.hidro.gov.ar).

C. Martinez, Facultad de Ciencias, Universidad de la República, Iguá 4225, 11400 Montevideo, Uruguay.

O.O. Möller Jr, Fundaçao Universidade do Rio Grande, Caixa Postal 474, Rio Grande, RS 96201-900, Brazil.

(Received December 11, 1998; revised August 12, 1999; accepted September 20, 1999.) 